\title{
Sulphur Dioxide Resistance in Saccharomyces cerevisiae and Saccharomycodes ludwigii
}

\author{
By MALCOLM STRATFORD, $†$ PHILIP MORGAN $\ddagger$ AND \\ A NTHONY H. ROSE* \\ Zymology Laboratory, School of Biological Sciences, Bath University, Bath, Avon BA2 7 AY, UK
}

(Received 24 November 1986; revised 4 March 1987)

\begin{abstract}
Saccharomyces ceretisiae was unable to grow in media containing above about $1.5 \mathrm{~mm}$ free sulphite at $\mathrm{pH} 4 \cdot 0$, whereas Saccharomycodes ludwigii grew at the same $\mathrm{pH}$ value in the presence of $7.8 \mathrm{~mm}$ free sulphite. Expressed in terms of $\mu \mathrm{l}$ of intracellular water, the initial velocity of sulphite accumulation by $S^{\prime}$ codes ludwigii was approximately twice that of $S$. cerevisiae, although the former yeast accumulated at equilibrium only about one-third of the amount of sulphite accumulated by $S$. cerevisiae. A Woolf-Hofstee plot for accumulation of $\mathrm{SO}_{2}$ by $S^{\prime}$ codes ludwigii at $\mathrm{pH} 3.0$ and $30^{\circ} \mathrm{C}$ gave a vertical line. Incorporation of sulphite in growth media induced excretion of acetaldehyde by both yeasts, the rate being greater by $S^{\prime}$ codes ludwigii than $S$. cerevisiae. Acetaldehyde excretion was accompanied by release of lower concentrations of pyruvate. Excretion of 2-oxoglutarate was barely detectable. It is suggested that the greater resistance of $S$ 'codes ludwigii to sulphite, compared with $S$. cerevisiae, may be explained partly by its decreased capacity to accumulate the compound, and partly by its ability to produce more acetaldehyde.
\end{abstract}

\section{INTRODUCTION}

Sulphite has long been known to be a powerful antimicrobial compound (Hammond \& Carr, 1976), although certain species of yeast are comparatively resistant to its action. Two factors complicate any study of the reaction of micro-organisms to sulphite. Firstly, the compound exists in three forms depending on the $\mathrm{pH}$ value. At $\mathrm{pH}$ values below 1.8 , sulphite exists predominately as free $\mathrm{SO}_{2}$ and at $\mathrm{pH}$ values above $7 \cdot 2$ largely as $\mathrm{SO}_{3}^{2-}$; at intermediate $\mathrm{pH}$ values, it exists in various proportions as the bisulphite ion $\left(\mathrm{HSO}_{3}^{-}\right)$. The $\mathrm{pK}$ value for the equilibrium $\mathrm{SO}_{2} \rightleftharpoons \mathrm{HSO}_{3}^{-}$is $1 \cdot 77$, and for the equilibrium $\mathrm{HSO}_{3}^{-} \rightleftharpoons \mathrm{SO}_{3}^{2-} 7 \cdot 20$ (King et al., 1981). In this paper, the term 'sulphite' is used to denote collectively all three forms. Secondly, sulphite reacts with compounds containing carbonyl groups to form $\alpha$-hydroxysulphonates, usually referred to as 'bound sulphite' (Burroughs \& Sparks, 1964a).

Although strains of Saccharomyces cererisiae are among the more sulphite-resistant of microorganisms (Wedzicha, 1984), little is known of the physiological basis of this resistance. At least some resistance is attributable to production of sulphite-binding compounds, primarily acetaldehyde, 2-oxoglutarate and pyruvate, when organisms are grown in the presence of sulphite (Rankine, 1968; Rankine \& Pocock, 1969; Weeks, 1969). It is also conceivable that differences in sulphite resistance of yeasts may be caused, in part at least, by different rates of transport of sulphite. Of the three molecular forms of sulphite, only free $\mathrm{SO}_{2}$ is transported into S. cererisiae (Macris \& Markakis, 1974). Stratford \& Rose (1986) showed that $\mathrm{SO}_{2}$ transport into $S$. cerevisiae is by free diffusion, so raising the possibility that the lipid composition of the plasma membrane may affect sulphite resistance in this yeast. Another yeast, Saccharomycodes ludwigii,

† Present address: AFRC Food Research Institute, Colney Lane, Norwich NR4 7UA, UK.

$\ddagger$ Present address: Shell Research, Sittingbourne Research Centre, Sittingbourne, Kent ME9 8AG, UK. 
is generally reckoned to be even more resistant to sulphite than $S$. cerevisiae, and is often isolated from alcoholic beverages that have been treated with sulphite at concentrations which prevent growth of $S$. cerevisiae (Amerine \& Kunkee, 1968; Beech \& Carr, 1977). Nothing has been reported on the physiological basis of sulphite resistance in $S^{\prime}$ codes ludwigii. The present paper compares the physiology of the reaction to sulphite of strains of $S$. cerevisiae and $S^{\prime}$ codes ludwigii.

\section{METHODS}

Organisms. The yeasts used, S. cerevisiae strain TC8 (Stratford and Rose, 1985), and S'codes ludwigii TC10, both provided by T. C. Cowland of the Taunton Cider Co, Norton Fitzwarren, Somerset, UK, were maintained on slopes of malt extract-yeast extract-glucose-mycological peptone (MYGP) agar (Wickerham, 1951).

Experimental cultures. The medium used was a modification of that described by Alterthum \& Rose (1973) and contained $\left(1^{-1}\right)$ : glucose, $20 \mathrm{~g} ;\left(\mathrm{NH}_{4}\right)_{2} \mathrm{SO}_{4}, 3.0 \mathrm{~g} ; \mathrm{KH}_{2} \mathrm{PO}_{4}, 3.0 \mathrm{~g}$; yeast extract (Difco), $1.0 \mathrm{~g} ; \mathrm{MgSO}_{4} .7 \mathrm{H}_{2} \mathrm{O}$, $25 \mathrm{mg}$; and $\mathrm{CaCl}_{2} .2 \mathrm{H}_{2} \mathrm{O}, 25 \mathrm{mg}$. The medium was buffered to $\mathrm{pH} 4.0$ by addition of $5.7 \mathrm{~g}$ citric acid and $6.0 \mathrm{~g}$ trisodium citrate $1^{-1}$. Sulphite was included in media by incorporating portions of a freshly prepared (Postgate, 1963) solution of $78 \mathrm{~mm}$-sodium metabisulphite to give the desired suiphur dioxide concentration. Portions (1 l $)$ of sterile medium in 21 round flat-bottomed flasks were inoculated with a starter culture to give experimental cultures containing $20 \mathrm{mg}$ dry wt organisms $\mathrm{l}^{-1}$. Starter cultures were prepared by inoculating $100 \mathrm{ml}$ portions of medium in a $250 \mathrm{ml}$ conical flask with a pinhead of yeast from a slope culture, and incubating for approximately $24 \mathrm{~h}$ on an orbital shaker ( 300 r.p.m.) at $30^{\circ} \mathrm{C}$. Experimental cultures were incubated at $30^{\circ} \mathrm{C}$ with stirring by a magnetic stirrer bar $(50 \mathrm{~mm}$ length). Growth was followed by measuring the optical density of portions of cultures at $600 \mathrm{~nm}$; these measurements were converted to $\mathrm{mg}$ dry wt organisms $\mathrm{ml}^{-1}$ using a calibration curve for each yeast.

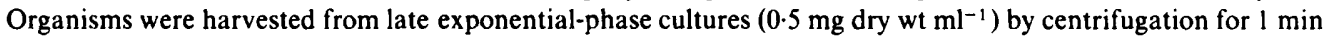
at $5000 \mathrm{~g}$ and $4{ }^{\circ} \mathrm{C}$, and washed twice with $10 \mathrm{ml} 30 \mathrm{~mm}$-citrate buffer (pH 4.0 unless otherwise stated). Alternatively, they were harvested by filtration through a membrane filter $(0.45 \mu \mathrm{m}$ pore size; $50 \mathrm{~mm}$ diam.; Oxoid) and washed twice with $10 \mathrm{ml}$ citrate buffer.

Viability measurements. Portions of culture were serially diluted in one-quarter strength Ringer's solution, and appropriate dilutions plated in duplicate on MYGP agar plates which were incubated for 3 days at $30^{\circ} \mathrm{C}$.

Disruption of organisms. Organisms were harvested by centrifugation to obtain a pellet containing $50 \mathrm{mg}$ dry wt equivalent. The pellet was resuspended in a minimal amount of sterile ice-cold citrate buffer $(30 \mathrm{~mm})$ and added to $30 \mathrm{~g}$ glass beads $(0.17-0.18 \mathrm{~mm}$ diam.; Braun) with sufficient buffer to form a thick slurry. The organisms were disrupted in a Braun homogenizer, cooled by liquid $\mathrm{CO}_{2}$, for a total period of $2 \mathrm{~min}$. Large cellular debris was removed by centrifugation for $10 \mathrm{~min}$ at $1200 \mathrm{~g}$ and $4{ }^{\circ} \mathrm{C}$. The supernatant was retained and stored at $4{ }^{\circ} \mathrm{C}$.

Measurement of initial velocities of $\mathrm{SO}_{2}$ accumulation. Organisms were harvested from late exponential-phase cultures $\left(0.5 \mathrm{mg} \mathrm{dry} \mathrm{wt} \mathrm{ml}^{-1}\right)$ by filtration, washed twice with $10 \mathrm{ml} 30 \mathrm{~mm}$-citrate buffer containing $100 \mathrm{mM}$ -

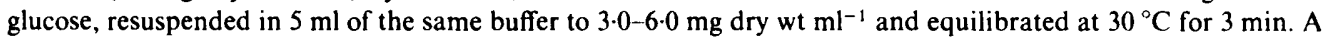
portion ( $1 \mathrm{ml}$ ) of the suspension was drawn into a BCL 8000 repetitive pipette (Boehringer) fitted with a $6 \mathrm{ml}$ syringe (Boehringer) followed immediately by $5 \mathrm{ml}$ citrate buffer containing $100 \mathrm{mM}$-glucose, $1.0 \mu \mathrm{M}-5.0 \mathrm{mM}$ sulphite and [ $\left.{ }^{35} \mathrm{~S}\right] \mathrm{sulphite}\left(1.85-0.74 \mathrm{kBq} \mathrm{ml}^{-1}\right)$. Portions $(0.5 \mathrm{ml})$ of the suspension were rapidly filtered at 1 or $2 \mathrm{~s}$ intervals through membrane filters $(0.45 \mu \mathrm{m}$ pore size; $25 \mathrm{~mm}$ diam; Millipore) and the filters with organisms quickly washed with $2 \mathrm{ml}$ citrate buffer containing $100 \mathrm{mM}$-glucose and non-radioactive sulphite at the concentration used in the experiment. Filters were prewashed with $10 \mathrm{ml} 10 \mathrm{~mm}$-non-radioactive sulphite (pH 4.0). Heat loss from the suspension over a $10 \mathrm{~s} \mathrm{sampling} \mathrm{period} \mathrm{was} \mathrm{negligible.} \mathrm{Filters} \mathrm{with} \mathrm{organisms} \mathrm{were}$ placed in scintillation vials containing $7 \mathrm{ml}$ Optiphase Safe (Fisons). Radioactivity in the vials was measured in a LK B RackBeta liquid scintillation spectrometer (model 1217). The suspension remaining in the pipette at the end of a sampling period was ejected into a scintillation vial containing Optiphase to check on the total radioactivity of the suspension. Accumulation of sulphite over longer periods (up to $5 \mathrm{~min}$ ) was followed using stirred suspensions of organisms in citrate buffer supplemented with $100 \mathrm{~mm}$-glucose and sulphite containing $\left.{ }^{35} \mathrm{~S}\right]$ sulphite as described by Stratford \& Rose (1986).

Relationship between dry wt of organisms and cytoplasmic volume. This was established by the method of Cole \& Keenan (1987). Organisms were suspended in a solution containing ${ }^{3} \mathrm{H}_{2} \mathrm{O}$, which equilibrates with both extracellular and intracellular water, and $\left[{ }^{1+} \mathrm{C}\right]$ mannitol which equilibrates with interstitial water and water in the wall but does not penetrate the plasma membrane. The difference in the extent of dilution of each labelled compound after mixing was used to calculate the relationship between dry wt of organisms and cytoplasmic

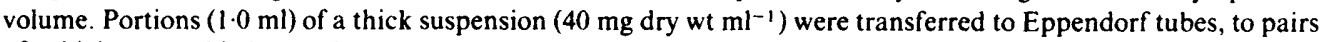
of which was added $0.1 \mathrm{ml}$ of a solution containing either ${ }^{3} \mathrm{H}_{2} \mathrm{O}\left(60 \mathrm{MBq} \mathrm{mol}^{-1}\right.$; final concn $\left.61.6 \mu \mathrm{M}\right)$ or $\mathrm{D}-\left[1{ }^{14} \mathrm{C}\right]$ mannitol $\left(2.02 \mathrm{MBq} \mu \mathrm{mol}^{-1}\right.$; final concn $\left.1.8 \mathrm{nM}\right)$. The contents of the tubes were then mixed by inversion and left to stand at room temperature $\left(20-22^{\circ} \mathrm{C}\right)$ for $5 \mathrm{~min}$. After centrifuging the tubes in a MSE Microcentaur $\left(12000 \mathrm{~g}, 20 \mathrm{~s}, 20^{\circ} \mathrm{C}\right)$, portions $(0.1 \mathrm{ml})$ of the supernatant were removed from each tube and added to scintillation 
vials containing $2 \mathrm{ml}$ Unisolve 1 (Koch-Light). Radioactivity in the vials was measured in a LKB Rack Beta liquid scintillation spectrometer. S. cerevisiae contained $2.61 \mu \mathrm{l}$ and $S^{\prime}$ codes ludwigii $1.43 \mu \mathrm{l}(\mathrm{mg} \mathrm{dry} \mathrm{wt})^{-1}$.

Analytical methods. Total $\mathrm{SO}_{2}$ was measured by the method of Burroughs \& Sparks (1963) and free $\mathrm{SO}_{2}$ by the Burroughs \& Sparks (1964b) method. Acetaldehyde was determined by a modification of the Burroughs \& Sparks (1961) method. Culture filtrate $(20 \mathrm{ml})$ was placed in a Markham steam-distillation apparatus, supplemented with $5 \mathrm{ml}$ phosphate buffer ( $35 \mathrm{~mm} ; \mathrm{pH} 7 \cdot 0)$ and sufficient $1 \mathrm{M}-\mathrm{NaOH}$ to neutralize the sample. The sample was then steam distilled for about $5 \mathrm{~min}$ into $5 \mathrm{ml}$ buffered $\mathrm{Na}_{2} \mathrm{~S}_{2} \mathrm{O}_{3}\left(56 \mathrm{gl}^{-1} ; \mathrm{pH} \mathrm{7.0)}\right.$ containing $\mathrm{Na}_{2}$ EDTA $\left(5 \mathrm{~g} \mathrm{l}^{-1}\right)$. To titrate the excess uncomplexed sulphite, the distillate was supplemented with $1 \mathrm{ml}$ each of $25 \%(\mathrm{v} / \mathrm{v}) \mathrm{HCl}$ and $1 \%$ $(\mathrm{w} / \mathrm{v})$ freshly prepared starch solution, and then titrated to a faint blue-black colour with iodine solution $(0.1 \mathrm{M}$ followed by $0.01 \mathrm{~m}$ ). Solid $\mathrm{NaHCO}_{3}$ was added to neutralize the $\mathrm{HCl}$, thereby dissociating the acetaldehydesulphite complex and liberating sulphite in the distillate, which was immediately titrated to a blue-black endpoint with 0.01 M-iodine solution. The latter titre volume multiplied by 11.0 (L. F. Burroughs, personal communication) gave the acetaldehyde concentration $\left(\mu \mathrm{g} \mathrm{l}^{-1}\right)$. Pyruvate was determined using a test kit (Boehringer) according to the method of Czok \& Lamprecht (1974), and 2-oxoglutarate as described by Bergmeyer \& Bernt (1974).

Chemicals. All reagents used were AnalaR or of the highest grade available commercially. Amersham supplied ${ }^{3} \mathrm{H}_{2} \mathrm{O},\left[{ }^{14} \mathrm{C}\right]$ mannitol and sodium $\left[{ }^{35} \mathrm{~S}\right]$ sulphite which was stored at $-20{ }^{\circ} \mathrm{C}$ in $5 \mathrm{mM}$-EDTA to avoid oxidation.

\section{RESULTS}

\section{Effect of sulphite on growth and viability}

Incorporating sulphite in media caused an increase in the lag phase of growth of both yeasts (Fig. 1). S. cerevisiae was unable to grow in the presence of $1.56 \mathrm{~mm}$-sulphite at pH 4.0 , but $S$ 'codes ludwigii was able to grow at this $\mathrm{pH}$ value in the presence of higher concentrations of sulphite (Fig. 1) up to and including $7.8 \mathrm{~mm}$ (not shown) although the lag phase at this concentration was about 41 h. S. cerevisiae was also much more sensitive than $S^{\prime}$ codes ludwigii to the lethal effect of sulphite, as assessed by the decline in viability of organisms suspended in media containing different concentrations of sulphite (Fig. 2).

\section{Velocities and extent of sulphite accumulation}

The initial velocity of sulphite accumulation $(1.0 \mathrm{~mm}, \mathrm{pH} 4.0)$ by $S$. cerevisiae was $47.5 \pm 4.9 \mathrm{nmol}(\mathrm{mg} \text { dry wt })^{-1} \mathrm{~min}^{-1}$, while that by $S^{\prime}$ codes ludwigii was $53.9 \pm 7.0 \mathrm{nmol}(\mathrm{mg}$ dry $\mathrm{wt})^{-1} \min ^{-1}$. These values are means of at least six separate determinations. Calculated on the basis of $\mu \mathrm{l}$ of intracellular water, the initial velocity of accumulation into $S$. cerevisiae was
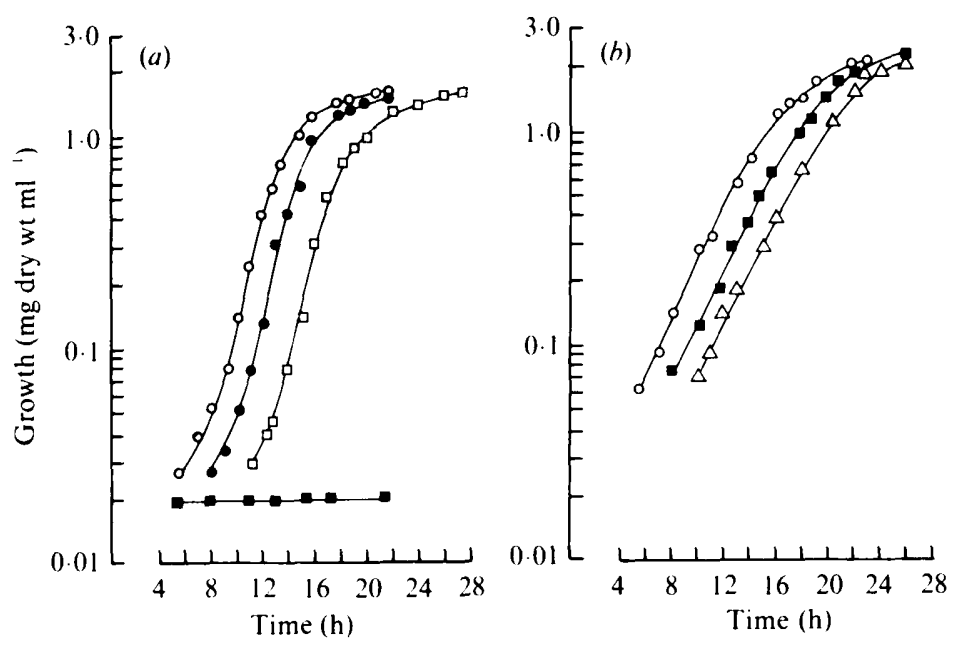

Fig. 1. Time-course of growth of $S$. cerevisiae $(a)$ and $S^{\prime}$ codes ludwigii $(b)$ in media (pH $\left.4 \cdot 0\right)$ either lacking sulphite $(O)$ or containing $0.31 \mathrm{~mm}(\bigcirc), 0.78 \mathrm{~mm}(\square), 1.56 \mathrm{~mm}(\square)$ or $3.12 \mathrm{~mm}(\triangle)$ total sulphite. Initial free sulphite concentrations were, respectively, 0.0,0.20, 0.66, 1.43 and $2.95 \mathrm{~mm}$. 

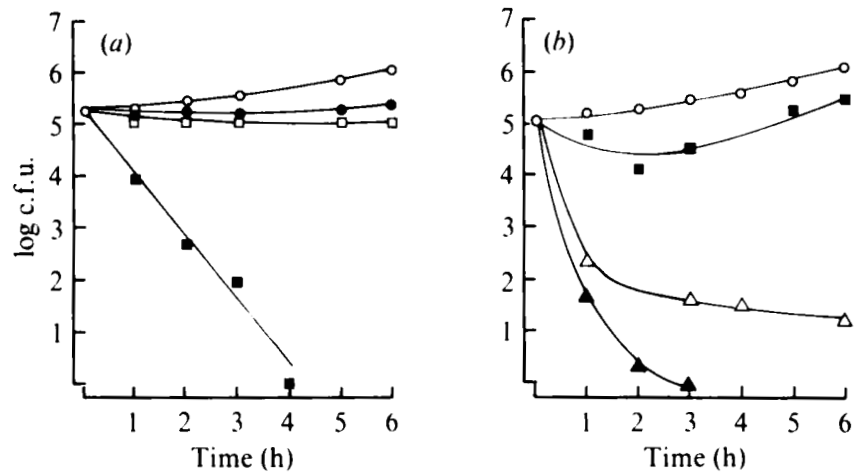

Fig. 2. Time-course of change in viability of populations of $S$. cerevisiae (a) and $S^{\prime}$ codes ludwigii (b) incubated with stirring at $30^{\circ} \mathrm{C}$ in media either lacking sulphite $(O)$, or containing $0.31 \mathrm{~mm}(O)$, $0.78 \mathrm{~mm}(\square), 1.56 \mathrm{~mm}(\boldsymbol{\square}), 7.80 \mathrm{~mm}(\triangle)$ or $15.60 \mathrm{~mm}(\Delta)$ total sulphite. Values given are the means of duplicate determinations.

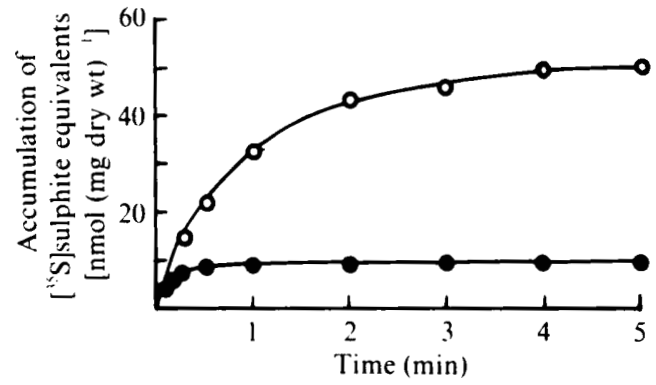

Fig. 3

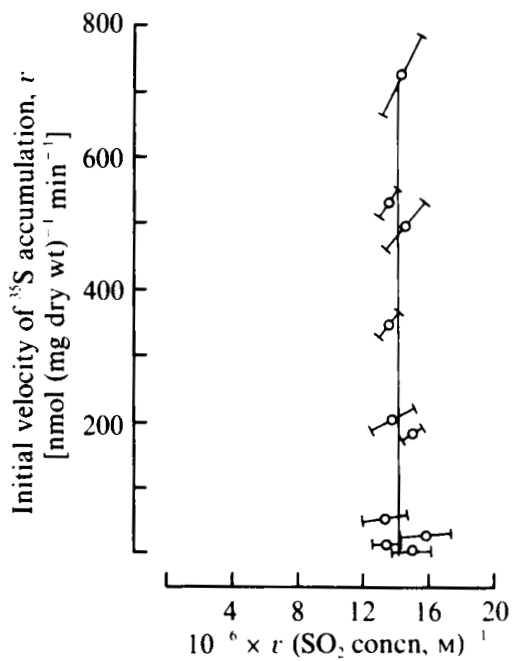

Fig. 4

Fig. 3. Time-course of accumulation at $30^{\circ} \mathrm{C}$ of sulphite equivalents by $S$. cerevisiae $(O)$ and $S^{\prime}$ codes ludwigii (O), each at $1.0 \mathrm{mg}$ dry wt $\mathrm{ml}^{-1}$, from $30 \mathrm{~mm}$-citrate buffer $(\mathrm{pH} 3 \cdot 0)$ containing glucose $(100 \mathrm{~mm})$ and $\left[{ }^{35} \mathrm{~S}\right]$ sulphite $(0.1 \mathrm{mM})$. Values quoted are means of at least six separate determinations.

Fig. 4. Woolf-Hofstee plot for accumulation of molecular $\mathrm{SO}_{2}$ by $\mathrm{S}^{\prime}$ codes ludwigii suspended in buffer at $\mathrm{pH} 3 \cdot 0$ and $30^{\circ} \mathrm{C}$. Concentrations of molecular $\mathrm{SO}_{2}$ were calculated from the data of King et al. (1981). Bars indicate SD.

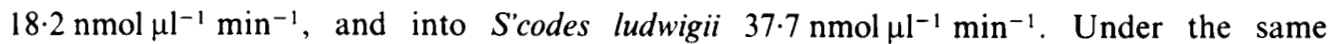
conditions, net accumulation by $S$. cerevisiae ceased at a value of $50.0 \pm 1.8 \mathrm{nmol}(\mathrm{mg} \text { dry wt })^{-1}$ and by $S^{\prime}$ codes ludwigii at $8.8 \pm 1.7 \mathrm{nmol}(\mathrm{mg} \text { dry wt) })^{-1}$ (Fig. 3). In terms of $\mu \mathrm{l}$ of intracellular water, net accumulation values were $19 \cdot 1 \mathrm{nmol} \mu \mathrm{l}^{-1}$ for $S$. cerevisiae and $6.2 \mathrm{nmol}^{-1}$ for S'codes ludwigii. A Woolf-Hofstee plot (Hofstee, 1959) for accumulation of $\mathrm{SO}_{2}$ by $\mathrm{S}^{\prime}$ codes ludwigii at $\mathrm{pH} 3.0$ and $30^{\circ} \mathrm{C}$ gave a vertical line (Fig. 4).

\section{Sulphite-induced production of binding compounds}

Growth of $S$. cerevisiae and S'codes ludwigii in media supplemented with sulphite was accompanied, over the first few hours of incubation, by disappearance of free sulphite from the 

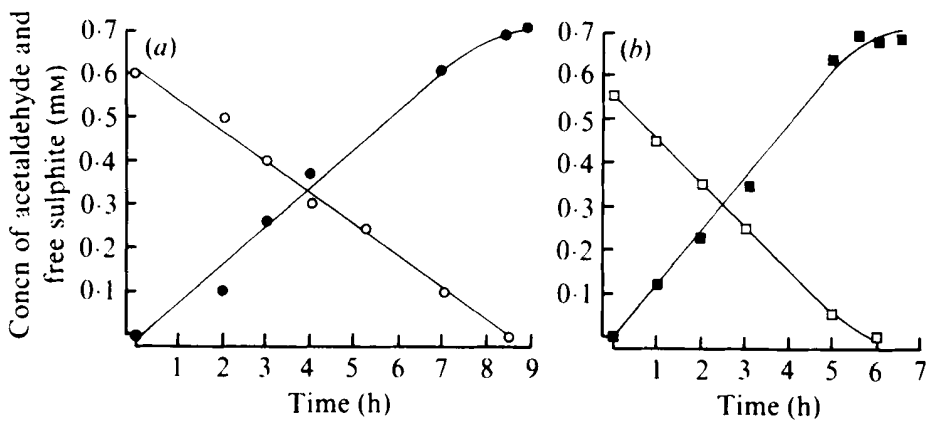

Fig. 5. Time-course of decline in the concentration of free sulphite $(O, \square)$ and of the increase in acetaldehyde concentration $(O, \square)$ in filtrates from cultures of $S$. cerevisiae $(a)$ and $S^{\prime}$ codes ludwigii $(b)$ during the early stages of growth.

medium and excretion of acetaldehyde. In media lacking $\mathrm{SO}_{2}$, neither yeast produced acetaldehyde. However, in the presence of $\mathrm{SO}_{2}$ the rate of production of acetaldehyde was greater by $S^{\prime}$ codes ludwigii than by $S$. cerevisiae. In a medium containing initially $0.55-0.60 \mathrm{~mm}$ free $\mathrm{SO}_{2}, S$. cerevisiae produced acetaldehyde at a rate of $88 \mu \mathrm{mol}^{-1} \mathrm{~h}^{-1}$, whereas $S^{\prime}$ codes ludwigii produced it at a rate of $126 \mu \mathrm{mol}^{-1} \mathrm{~h}^{-1}$ (Fig. 5). During suspension of S. cerevisiae in media supplemented with sulphite in the range $0 \cdot 20-0.72 \mathrm{mmol}^{-1}$, acetaldehyde was produced in amounts that represented a mean excess of about $4 \%$ over those required to bind the sulphite initially present. S'codes ludwigii, suspended in media with initial sulphite concentrations in the range $0.55-5.83 \mathrm{mmol}^{-1}$, produced acetaldehyde in amounts that were on average $25 \%$ in excess of those required to bind the sulphite initially present. Sulphite-induced production of acetaldehyde was accompanied by production of pyruvate in amounts that, in cultures of $S$. cerevisiae, were $20-40 \%$ of the amount of acetaldehyde produced; in cultures of S'codes ludwigii they were negligible. Production of 2-oxoglutarate was barely detectable in any of the cultures. When supernatants $(10 \mathrm{ml} ; \mathrm{pH} 4.0)$ from suspensions of $50 \mathrm{mg}$ dry wt equivalent of disrupted $S$. cerevisiae or $S^{\prime}$ codes ludwigii were supplemented with sulphite $(92.8 \mathrm{~mm})$ and incubated at $4{ }^{\circ} \mathrm{C}$ for $30 \mathrm{~min}$, virtually identical proportions of sulphite were bound in both mixtures.

\section{DISCUSSION}

Although it has often been claimed that $S^{\prime}$ codes ludwigii is more resistant to sulphite than $S$. cerevisiae, which itself is more sulphite-resistant than most other yeasts (Hammond \& Carr, 1976; Beech \& Carr, 1977), this paper is the first to describe differences in sulphite sensitivity between these two yeasts in quantitative terms. In sulphite-containing media, both yeasts showed an increase in the lag phase of growth and a loss of colony-forming ability. While these effects were observed with $S$. cerevisiae in the range of sulphite concentrations in which they were examined by Schimz (1980), they were only observed to take place with $S$ 'codes ludwigii at very much higher concentrations. Transport of $\mathrm{SO}_{2}$ into $S$. cerevisiae at $\mathrm{pH} 3.0$ is by simple diffusion (Stratford \& Rose, 1986). The vertical Woolf-Hofstee plot obtained in the present study with S'codes ludwigii, also examined at pH 3.0 to increase the concentration of $\mathrm{SO}_{2}$, indicates that this yeast does not have a finite Michaelis constant for molecular $\mathrm{SO}_{2}$, which in turn suggests that passage of $\mathrm{SO}_{2}$ into it is also by simple diffusion.

A significant finding made in the present study was that the amount of sulphite accumulated intracellularly was greater in $S$. cerevisiae than in $S^{\prime}$ codes ludwigii. Expressed in the physiologically more significant terms of $\mu \mathrm{l}$ cytoplasmic volume, initial velocities of sulphite accumulation were greater with $S$ 'codes ludwigii than with $S$. cerevisiae. This finding is of interest in relation to the report (Kaneko et al., 1976) that $S^{\prime}$ codes ludwigii is richer than $S$. cerevisiae in $\mathrm{C}_{18: 1}$ phospholipid fatty-acyl residues which might indicate that a greater membrane fluidity facilitates diffusion of $\mathrm{SO}_{2}$ across the plasma membrane. 
Although sulphite, mainly in the form of molecular $\mathrm{SO}_{2}$, has been shown to react with a wide variety of cell constituents, principally molecules containing carbonyl groups (Wedzicha, 1984), it is now thought that the initial reaction of $S$. cerevisiae with sulphite, at concentrations up to 10-15 mM, leads to depletion of cellular ATP (Schimz \& Holzer, 1979) mainly as a result of inactivation of glyceraldehyde-3-phosphate dehydrogenase (Hinze \& Holzer, 1986). It is very likely that $S$. cerevisiae and $S^{\prime}$ codes ludwigii contain ATP pools of approximately the same size, and also produce ATP at about the same rates. To explain the different reaction of these yeasts to sulphite, one possibility is that they differ in the extent to which exogenous molecular $\mathrm{SO}_{2}$ has access to those intracellular targets that are involved in ATP generation. An alternative explanation is that glyceraldehyde-3-phosphate dehydrogenases in the two yeasts differ in sensitivity to $\mathrm{SO}_{2}$.

When molecular $\mathrm{SO}_{2}$ enters the yeast cell by diffusion, it encounters an environment which is at a higher $\mathrm{pH}$ value than that prevailing outside the cell. As a result, a proportion of the $\mathrm{SO}_{2}$ entering the cell is converted into $\mathrm{HSO}_{3}^{-}$which, since it cannot leave the cell, forms an effective intracellular sulphite trap (Stratford \& Rose, 1986), the magnitude of which will depend on the intracellular $\mathrm{pH}$ value. Another possible explanation, therefore, for the differences observed in the present study in the reaction of $S$. cerevisiae and $S^{\prime}$ codes ludwigii to sulphite is that, assuming equal internal buffering capacity, the latter yeast has a lower internal $\mathrm{pH}$ value than $S$. cerevisiae.

Another factor which must be taken into account in any explanation of the different responses of the two yeasts to sulphite is the greater production of acetaldehyde by S'codes ludwigii. However, this is unlikely to help explain the smaller uptake of sulphite by this yeast, since data on net accumulation were obtained using organisms suspended in solutions lacking a carbon source and so under conditions that would not induce organisms to produce significant amounts of acetaldehyde. Nor is there evidence using extracts of organisms of a difference in the concentration of sulphite-binding compounds inside the two yeasts. The relevance of the different capacities to produce acetaldehyde in the presence of sulphite, in relation to their different sulphite tolerances, remains to be elucidated.

Malcolm Stratford thanks the SERC and the Taunton Cider Company for a CASE studentship. We are grateful to Martin Cole for assistance in measurements of intracellular water volumes of organisms. Jill Calderbank generously assisted in the preparation of the paper.

\section{REFERENCES}

Alterthum, F. \& Rose, A. H. (1973). Osmotic lysis of sphaeroplasts from Saccharomyces cerevisiae grown anaerobically in media containing different unsaturated fatty acids. Journal of General Microbiology 77, 371-382.

AMERINe, M. A. \& KunkeE, R. E. (1968). Microbiology of winemaking. Annual Review of Microbiology 77, 323-358.

BEECH, F. W. \& CARR, J. G. (1977). Cider and perry. In Economic Microbiology, vol. 1, Alcoholic Beverages, pp. 139-313. Edited by A. H. Rose. London: Academic Press.

BERGMEYER, H.-U. \& BERNT, E. (1974). 2-Oxoglutarate, UV spectrophotometric determination. In Methods of Enzymatic Analysis, vol. 3, pp. 1577 1584. Edited by H.-U. Bergmeyer. New York: Academic Press.

Burroughs, L. F. \& Sparks, A. H. (1961). The iodometric determination of acetaldehyde bisulphite. Analyst 86, 381-385.

Burroughs, L. F. \& Sparks, A. H. (1963). The determination of the total sulphur dioxide contents of ciders. Analyst 88, 304-309.

Burroughs, L. F. \& Sparks, A. H. (1964a) The identification of sulphur dioxide-binding compounds in apple juices and ciders. Journal of the Science of Food and Agriculture 15, 176-185.

Burroughs, L. F. \& Sparks, A. H. (1964b). The determination of the free sulphur dioxide contents of ciders. Analyst 89, 55-60.

Cole, M. \& Keenan, M. H. J. (1987). Mechanism of weak-acid resistance and control of intracellular $\mathrm{pH}$ of Zygosaccharomyces bailii. Yeast 3, 23-33.

CzoK, R. \& Lamprecht, W. (1974). Pyruvate, phosphoenol pyruvate and D-glycerate-2-phosphate. In Methods of Enzymatic Analysis, vol. 3, pp. 14461551. Edited by H.-U. Bergmeyer. New York: Academic Press.

Hammond, S. M. \& CARR, J. G. (1976). The antimicrobial activity of $\mathrm{SO}_{2}$ with particular reference to fermented and non-fermented fruit juices. In Inhibition and Inactivation of Vegetative Microbes, pp. 89110. Edited by F. A. Skinner \& W. B. Hugo. London: Academic Press.

HiNZE, H. \& HOLZER, H. (1986). Analysis of the energy metabolism after incubation of Saccharomyces cerevisiae with sulfite or nitrite. Archives of Microbiology 145, 27-31. 
HofsteE, B. H. J. (1959). Non-inverted versus inverted plots in enzyme kinetics. Nature, London 184, 12961298.

Kaneko, H., Hosahara, M., Tanaka, M. \& Itoh, T. (1976). Lipid composition of 30 species of yeast Lipids 11, 837-844.

King, A. D., JR, Ponting, J. D., Sanschuck, D. W., JACKSON, R. \& MiHARA, K. (1981). Factors affecting death of yeast by sulphur dioxide. Journal of Food Protection 44, 92-97.

Macris, B. J. \& Markakis, P. (1974). Transport and toxicity of sulphur dioxide in Saccharomyces cerevisiae var. ellipsoides. Journal of the Science of Food and Agriculture 25, 21-29.

Postgate, J. R. (1963). The examination of sulphur auxotrophs: a warning. Journal of General Microbiology 30, 481-484.

RANKINE, B. C. (1968). Formation of $\alpha$-ketoglutaric acid by wine yeasts and its oenological significance. Journal of the Science of Food and Agriculture 19, 624 627.

Rankine, B. C. \& Pocock, K. F. (1969). Influence of yeast strain on binding of sulphur dioxide in wines and on its formation during fermentation. Journal of the Science of Food and Agriculture 20, 104-109.
Schimz, K.-L. (1980). The effect of sulphite on the yeast Saccharomyces cerevisiae. Archives of Microbiology 125, 89-95.

SCHIMZ, K.-L. \& Holzer, H. (1979). Rapid decrease of ATP content in intact cells of Saccharomyces cerevisiae after incubation with low concentrations of sulfite. Archives of Microbiology 121, 225-229.

StratFord, M. \& Rose, A. H. (1985). Hydrogen sulphide production from sulphite by Saccharomyces cerevisiae. Journal of General Microbiology 131, 14171424.

StratFord, M. \& Rose, A. H. (1986). Transport of sulphide dioxide by Saccharomyces cerevisiae. Journal of General Microbiology 132, 1-6.

WEDZICHA, B. L. (1984). Chemistry of Sulphur Dioxide in Foods. Amsterdam: Elsevier.

WeEks, C. (1969). Production of sulphur dioxidebinding compounds and of sulphur dioxide by two Saccharomyces yeasts. American Journal of Enology and Viticulture 20, 32-39.

WiCKERHAM, L. J. (1951). Taxonomy of yeasts. I. Techniques of classification. United States Department of Agriculture Technical Bulletin, no. 1029. Washington, DC: US Department of Agriculture. 